\title{
PENGEMBANGAN BUKU PETUNJUK PRAKTIKUM KIMIA ANORGANIK YANG DISERTAI DENGAN MATERIAL SAFETY DATA SHEET
}

\author{
Rusly Hidayah ${ }^{1}$, Dina Kartika Maharani2 ${ }^{2}$ \\ 1,2Jurusan Kimia FMIPA Universitas Negeri Surabaya
}

\begin{abstract}
Abstrak - Penelitian ini bertujuan untuk mengembangkan buku petunjuk praktikum kimia anorganik yang disertai dengan Material Data Sheet. Untuk mengetahui kevalidan, kepraktisan, dan keefektifan dari buku petunjuk praktikum yang dikembangkan, maka dilakukan penelitian pengembangan mengacu pada R \& D yang dikemukakan oleh Plomp (2010). Data hasil penelitian dianalisis menggunakan statistik deskriptif. Dari hasil analisis diperoleh beberapa temuan sebagai berikut: (1) buku petunjuk praktikum yang dikembangkan telah valid ditinjau dari kriteria isi, kriteria kebahasaan, kriteria penyajian, dan kriteria kegrafikan; (2) buku petunjuk praktikum yang dikembangkan telah praktis ditinjau dari angket respon mahasiswa dan hasil observasi aktivitas mahasiswa; (3) buku petunjuk praktikum yang dikembangkan telah efektif ditinjau dari hasil belajar mahasiswa.
\end{abstract}

Kata kunci: pengembangan, buku petunjuk praktikum, Material Safety Data Sheet

\begin{abstract}
The purpose of this research is to develop experimental guidance book for inorganic chemistry with material safety data sheet. Design of development experimental guidance book was R \& D by Plomp (2010). Data of the research was analyzed by descriptive statistic. The result of the research were: (1) the experimental guidance book in developing are good in content validity, language validity, presentation validity, and graphic validity; (2) the experimental guidancw book in developing are practice based on university students response and university students activity; (3) the experimental guidance book in developing are efective based on learning outcome.
\end{abstract}

Keywords: development, experimental guidance book, Material Safety Data Sheet

\section{PENDAHULUAN}

Praktikum sering dianggap sebagai sebuah pekerjaan yang istimewa, karena mahasiswa menghabiskan lebih banyak waktu untuk jumlah SKS yang sama (Utomo, 2010). Praktikum kimia anorganik bertujuan agar mahasiswa memiliki kompetensi dalam mengenali sifat periodik unsur-unsur dan mengenali karakteristik spesies anorganik terutama dalam bentuk senyawanya. Praktikum merupakan strategi pembelajaran atau bentuk pengajaran yang digunakan untuk membelajarkan secara bersama-sama kemampuan psikomotorik (keterampilan), pengertian (pengetahuan), dan afektif (sikap) menggunakan sarana laboratorium (Zainuddin, 2001). Laboratorium sebagai tempat pelaksanaan praktikum menuntut kesungguhan yang tinggi. Menurut Moran (2010), meski bergantung pada panduan dosen, mahasiswa yang sebenarnya melakukan 
kegiatan praktikum. Mereka harus bekerja dengan bahan kimia yang mereka gunakan secara aman dan selamat. Semua orang yang bekerja di laboratorium bertanggung jawab mematuhi keselamatan dan keamanan untuk melindungi diri mereka sendiri dan orang lain.

Kecelakaan kerja paling banyak disebabkan oleh perilaku tidak aman, sisanya adalah kondisi yang tidak aman. Menurut hasil penelitian National Safety Council (2011), penyebab kecelakaan kerja karena unsafe behaviour (88\%), unsafe condition (10\%), dan tidak diketahui penyebabnya $(2 \%)$. Oleh karena itu, semua yang akan melakukan praktikum, yaitu praktikan, wajib menggunakan alat pelindung, memahami penanganan bahan kimia, maupun alat yang digunakan. Untuk mengetahui penanganan bahan kimia yang digunakan, praktikan harus sudah membaca Material Safety Data Sheet (MSDS). Menurut Peraturan Menteri Perindustrian RI [5], Material Safety Data Sheet (MSDS) atau Lembar Data Keselamatan Bahan (LDKB) merupakan lembar petunjuk yang berisi informasi bahan kimia meliputi sifat fisika, sifat kimia, jenis bahaya yang ditimbulkan, cara penanganan, tindakan khusus dalam keadaan darurat, dan informasi yang diperlukan. Secara ringkas, MSDS adalah kumpulan data keselamatan dan petunjuk dalam penggunaan bahan-bahan kimia berbahaya.

Buku petunjuk praktikum adalah salah satu media pembelajaran yang berisi tentang pelaksanaan kegiatan-kegiatan praktikum yang berisi prosedur praktikum sehingga dapat membantu dalam kelancaran proses kegiatan praktikum. Buku petunjuk praktikum yang digunakan saat ini, belum dilengkapi dengan MSDS. Padahal, hal tersebut sangat penting bagi praktikan sebagai salah satu upaya untuk mengetahui penanganan dan kehati-hatian dalam penggunaan bahan kimia dalam kegiatan praktikum. Untuk itu, perlu disusun buku petunjuk praktikum yang dilengkapi dengan MSDS.

\section{METODE}

Jenis penelitian merupakan penelitian pengembangan dengan model pengembangan yang diadaptasi dari Plomp [6] yang terdiri dari tiga fase yaitu preliminer, prototipe, dan asesmen. Uji coba dilakukan pada 20 mahasiswa jurusan kimia program studi kimia kelas KB 2014 dengan metode eksperimen one group pretest-posttest design. Data yang diperlukan diperoleh dari metode lembar telaah, lembar validasi, angket respon mahasiswa, lembar observasi aktivitas mahasiswa, dan tes hasil belajar.

Data yang diperoleh dari hasil telaah dosen kimia, diolah secara deskriptif kualitatif sebagai saran dan pertimbangan untuk perbaikan draft buku petunjuk praktikum yang dikembangkan. Data hasil validasi yang diperoleh dari dosen kimia terhadap buku petunjuk praktikum yang dikembangkan dianalisis secara kuantitatif. Analisis ini dilakukan pada setiap aspek (point) pada setiap kriteria yang berhubungan dengan komponen isi, kebahasaan, dan kegrafikan. Indikator penilaiannya berdasarkan nilai skala Likert (dalam Riduwan [7]). Nilai skala Likert dapat dilihat pada Tabel 1. Data hasil penilaian skor dianalisis dengan menggunakan rumus untuk menentukan persentase: 
Persentase $(\%)=\frac{\sum \text { skor hasil pengumpulan data }}{\text { skor kriteria }} \times 100 \%$

Skor kriteria $=$ skor tertinggi $x$ jumlah aspek $x$ jumlah responden

Tabel 1. Skala Likert

\begin{tabular}{cc}
\hline Nilai Skala & Penilaian \\
\hline 1 & Sangat kurang \\
2 & Kurang \\
3 & Cukup \\
4 & Baik \\
5 & Sangat baik \\
\hline
\end{tabular}

Tabel 2. Kriteria Persentase Skala Likert

\begin{tabular}{cc}
\hline Persentase (\%) & Kriteria \\
\hline $0-20$ & Sangat Kurang \\
$21-40$ & Kurang \\
$41-60$ & Cukup \\
$61-80$ & Baik \\
$81-100$ & Sangat Baik \\
\hline
\end{tabular}

Persentase yang diperoleh diinterpretasikan ke dalam kriteria yang dapat dilihat pada tabel 2. Berdasarkan kriteria tersebut, buku petunjuk praktikum dalam penelitian ini dikatakan memenuhi kriteria apabila persentase untuk validitas isi, kebahasaan dan kegrafikan masing-masing berada pada kriteria baik atau sangat baik dengan persentase $\geq 61 \%$, sehingga layak untuk digunakan dalam pembelajaran.

Hasil angket respon mahasiswa terhadap buku petunjuk praktikum yang dikembangkan dianalisis dengan mempresentasikan hasil jawaban siswa dengan rumus:

$P=\frac{F}{N} \times 100 \%$

Keterangan:

$\mathrm{P}=$ presentase jawaban responden

$\mathrm{F}=$ jumlah responden yang menjawab

$\mathrm{N}=$ jumlah responden

Kemudian hasil dari respon mahasiswa dapat dikategorikan ke dalam kriteria seperti yang terdapat pada tabel 3. Berdasarkan kriteria tersebut, buku petunjuk praktikum dalam penelitian ini dikatakan layak apabila berada pada kriteria baik atau sangat baik dengan persentase $\geq 61 \%$. Hasil observasi aktivitas mahasiswa dianalisis secara deskriptif kuantitatif yaitu hasil observasi dideskripsikan untuk memberikan gambaran tentang aktivitas yang dilakukan saat praktikum berlangsung selama ujicoba terbatas berlangsung. Aktivitas mahasiswa diamati dan dicatat oleh pengamat pada lembar observasi aktivitas mahasiswa selama kegiatan berlangsung. hasil belajar mahasiswa dilakukan untuk mengetahui penguasaan konsep mahasiswa dengan buku petunjuk praktikum yang dikembangkan tentang keselamatan kerja di laboratorium. Soal-soal pretest dan posttest yang digunakan adalah soal pilihan ganda (obyektif). Pencapaian kompetensi dinilai menggunakan skala 0-100 yang selanjutnya dikonversi ke dalam predikat A sampai E 
Tabel 3 Kriteria Persentase Skala Likert

\begin{tabular}{cc}
\hline Presentase & Kategori \\
\hline $0 \%-20 \%$ & Sangat Kurang \\
$21 \%-40 \%$ & Kurang \\
$41 \%-60 \%$ & Cukup \\
$61 \%-80 \%$ & Baik \\
$81 \%-100 \%$ & Sangat Baik \\
\hline
\end{tabular}

\section{PEMBAHASAN}

Rancangan penelitian yang digunakan adalah mengadaptasi model pengembangan Plomp [8] yang terdiri dari tiga fase yaitu fase penelitian preliminer, fase pembuatan prototipe, dan fase asesmen. Ketiga fase tersebut dapat diuraikan sebagai berikut:

1. Fase penelitian preliminer

Fase penelitian preliminer dilakukan untuk menentukan masalah dasar yang diperlukan untuk mengembangkan buku petunjuk praktikum. Pada tahap ini dilakukan investigasi awal dengan melihat adanya perkuliahan praktikum kimia anorganik yang harus memiliki buku petunjuk praktikum yang menunjang proses pembelajaran.

2. Fase pembuatan prototipe

Pada tahap ini, desain yang ditujukan untuk menghasilkan prototipe. Desain prototipe berupa buku petunjuk praktikum yang dilengkapi dengan MSDS. Selain itu, diperlukan pula desian instrumen meliputi instrumen kevalidan, kepraktisan, dan keefektifan.

a. Desain prototipe

Desain prototipe berupa buku petunjuk praktikum kimia anorganik yang disertai dengan MSDS, beberapa standar acuan label bahan kimia dan cara penggunaan alat pemadam kebakaran.

b. Desain instrumen

1) Instrumen kevalidan

Instrumen kevalidan berupa lembar validasi yang didesain untuk mengetahui umpan balik para validator. Sebelum dilakukan validasi, buku petunjuk praktikum ditelaah terlebih dahulu oleh penelaah.

2). Instrumen kepraktisan

Instrumen kepraktisan berupa lembar angket respon mahasiswa. Lembar respon ini didesain untuk mengetahui umpan balik para pengguna yaitu mahasiswa yang ditinjau dari beberapa aspek. Respon mahasiswa ditunjang pula dengan lembar observasi aktivitas mahasiswa selama menggunakan buku petunjuk praktikum. Aktivitas mahasiswa yang diamati yaitu aktivitas masing-masing mahasiswa yang diamati oleh observer. 


\section{3). Instrumen keefektifan}

Instrumen keefektifan berupa tes tertulis yang terdiri dari pretest dan posttest. Penyusunan tes tulis dalam penelitian ini difokuskan tentang keselamatan kerja di laboratorium.

\section{Fase Asesmen}

Pada fase ini dilakukan dua kegiatan yaitu validasi buku petunjuk praktikum dan uji coba terbatas.

\section{a. Telaah dan Validasi Kelengkapan Permainan}

Prototipe 1 yang dihasilkan pada fase pembuatan prototipe sebelumnya ditelaah oleh 2 dosen Kimia FMIPA Unesa untuk memperoleh saran atau masukan mengenai buku petunjuk praktikum yang dikembangkan. Hal ini bertujuan agar tidak terjadi kesalahan-kesalahan yang berimbas buruk pada saat tahapan validasi dan untuk kesempurnaan buku petunjuk praktikum. Beberapa saran atau masukan penelaah mengenai buku petunjuk praktikum adalah Memperbesar judul buku dan MSDS diletakkan setelah petunjuk praktikum. Setelah hasil telaah, maka dilakukan revisi, sehingga dihasilkan prototipe 2. Setelah itu, prototipe 2 tersebut divalidasi. Validasi bertujuan untuk mengetahui kelayakan buku petunjuk praktikum. Validasi dinilai oleh 2 orang dosen Kimia FMIPA Unesa. Validator mengisi lembar validasi.

Penilaian dilakukan dengan cara memilih satu diantara lima tingkat penilaian. Data dari hasil penilaian validator akan dianalisis secara deskriptif kuantitatif untuk mengetahui kelayakan buku petunjuk praktikum. Jika setelah diolah, hasil penelitian menunjukan tidak valid maka akan dilakukan revisi besar dan setelah itu, dilakukan analisis hasil validasi ulang hingga buku petunjuk praktikum yang dikembangkan mendapat kategori valid atau layak digunakan.

Berdasarkan hasil penilaian oleh validator, maka diperoleh validitas berdasarkan kriteria isi dengan persentase sebesar 95\% dan dapat diinterpretasikan bahwa buku petunjuk praktikum berdasarkan kriteria isi mendapatkan kriteria sangat baik. Validitas berdasarkan kriteria kebahasaan memperoleh persentase sebesar 86\% yang menunjukkan bahwa buku petunjuk praktikum mendapatkan kriteria sangat baik. Validitas berdasarkan kriteria penyajian mendapatkan persentase sebesar 94\% yang menunjukkan bahwa buku petunjuk praktikum mendapatkan kriteria sangat baik. Hal ini didukung oleh Sadiman [8] bahwa kegunaan buku petunjuk praktikum adalah untuk memperjelas penyajian pesan agar tidak terlalu bersifat verbalistis (dalam bentuk katakata tertulis atau lisan belaka). Penggunaan buku petunjuk praktikum secara tepat dan bervariasi dapat mengatasi sikap pasif mahasiswa. Validitas berdasarkan kriteria kegrafikan juga mendapatkan kriteria sangat baik dengan presentase sebesar 96\%. Hal ini menunjukkan bahwa buku petunjuk praktikum yang dikembangkan sangat valid digunakan pada mata kuliah kimia anorganik dan dapat digunakan untuk menyalurkan materi perkuliahan yang disampaikan dosen kepada mahasiswa. Hal tersebut, didukung dengan teori yang disampaikan oleh Sadiman [8] yang menyatakan bahwa buku petunjuk praktikum merupakan segala sesuatu yang dapat digunakan untuk menyalurkan pesan dari pengirim ke penerima sehingga dapat merangsang pikiran, perasaan dan perhatian mahasiswa sedemikian rupa selama proses belajar berlangsung. 
Berdasarkan keempat kriteria kevalidan, maka dapat disimpulkan bahwa buku petunjuk praktikum layak digunakan untuk diteruskan pada tahap uji coba terbatas.

Tabel 4. Hasil Penilaian oleh Validator

\begin{tabular}{|c|c|c|c|c|c|}
\hline \multirow{2}{*}{ No. } & \multirow{2}{*}{ Aspek yang Dinilai } & \multicolumn{2}{|c|}{ Skor Hasil Penilaian } & \multirow{2}{*}{$\% \mathbf{P}$} & \multirow{2}{*}{ Kriteria } \\
\hline & & $\mathrm{V}-1$ & $\mathrm{~V}-2$ & & \\
\hline \multicolumn{6}{|c|}{ Kriteria Isi } \\
\hline 1. & $\begin{array}{l}\text { Penyajian buku petunjuk praktikum } \\
\text { sesuai dengan taraf pemahaman dan } \\
\text { kemampuan membaca mahasiswa. }\end{array}$ & 5 & 5 & 100 & Sangat Baik \\
\hline 2. & $\begin{array}{l}\text { Materi di dalam buku petunjuk } \\
\text { praktikum logis dan sistematis } \\
\text { berdasarkan urutan pengetahuan yang } \\
\text { akan diberikan. }\end{array}$ & 5 & 5 & 100 & Sangat Baik \\
\hline 3. & $\begin{array}{l}\text { Fakta, konsep, dan ilustrasi yang } \\
\text { disajikan akurat. }\end{array}$ & 5 & 5 & 100 & Sangat Baik \\
\hline 4. & $\begin{array}{l}\text { Materi pendukung pembelajaran yang } \\
\text { disajikan (fitur dan contoh) dapat } \\
\text { menambah wawasan mahasiswa. }\end{array}$ & 4 & 4 & 80 & Baik \\
\hline \multicolumn{6}{|c|}{$\begin{array}{ll}\text { Kriteria Kebahasaan } \\
\end{array}$} \\
\hline 1. & $\begin{array}{l}\text { Penulisan buku petunjuk praktikum } \\
\text { menggunakan bahasa yang singkat, jelas } \\
\text { dan mudah dibaca. }\end{array}$ & 4 & 5 & 93,3 & Sangat Baik \\
\hline 2. & $\begin{array}{l}\text { Penulisan buku petunjuk praktikum } \\
\text { menggunakan ejaan dan bahasa } \\
\text { Indonesia yang baik dan benar. }\end{array}$ & 4 & 4 & 80 & Baik \\
\hline 3. & $\begin{array}{l}\text { Keruntutan bahasa dan keterkaitan antar } \\
\text { sub-bab, paragrap, dan kalimat. }\end{array}$ & 5 & 5 & 100 & Sangat Baik \\
\hline 4. & $\begin{array}{l}\text { Penulisan buku petunjuk praktikum } \\
\text { menggunakan istilah yang tepat dan } \\
\text { mudah dipahami. }\end{array}$ & 4 & 4 & 80 & Baik \\
\hline 5. & $\begin{array}{l}\text { Penulisan buku petunjuk praktikum } \\
\text { menggunakan istilah, simbol atau } \\
\text { lambang secara ajeg }\end{array}$ & 4 & 4 & 80 & Baik \\
\hline \multicolumn{6}{|c|}{ Kriteria Penyajian } \\
\hline 1. & $\begin{array}{l}\text { Cover mempresentasikan isi naskah buku } \\
\text { petunjuk praktikum. }\end{array}$ & 5 & 5 & 100 & Sangat Baik \\
\hline 2. & $\begin{array}{l}\text { Kejelasan indikator pembelajaran yang } \\
\text { ingin dicapai. }\end{array}$ & 4 & 4 & 80 & Baik \\
\hline 3. & $\begin{array}{l}\text { Penyajian buku petunjuk praktikum } \\
\text { membangkitkan rasa ingin tahu. }\end{array}$ & 4 & 5 & 93,3 & Sangat Baik \\
\hline 4. & $\begin{array}{l}\text { Kesesuaian ilustrasi dengan materi } \\
\text { pokok. }\end{array}$ & 4 & 5 & 93,3 & Sangat Baik \\
\hline 5. & $\begin{array}{l}\text { Ilustrasi atau gambar dapat membantu } \\
\text { pemahaman konsep. }\end{array}$ & 5 & 5 & 100 & Sangat Baik \\
\hline 6. & $\begin{array}{l}\text { Penyajian gambar disertai dengan } \\
\text { rujukan. }\end{array}$ & 4 & 4 & 80 & Baik \\
\hline 7. & Penyajian materi berpusat pada siswa. & 5 & 5 & 100 & Sangat Baik \\
\hline 8. & $\begin{array}{l}\text { Penulisan daftar pustaka sesuai dengan } \\
\text { aturan yang berlaku. }\end{array}$ & 5 & 5 & 100 & Sangat Baik \\
\hline 9. & $\begin{array}{l}\text { Penyajian buku petunjuk praktikum } \\
\text { menarik dan menyenangkan }\end{array}$ & 5 & 5 & 100 & Sangat Baik \\
\hline 10. & $\begin{array}{l}\text { Kelengkapan penyajian: Pendahuluan, } \\
\text { daftar isi dan daftar pustaka }\end{array}$ & 5 & 5 & 100 & Sangat Baik \\
\hline
\end{tabular}




\begin{tabular}{|c|c|c|c|c|c|}
\hline \multirow{2}{*}{ No. } & \multirow{2}{*}{ Aspek yang Dinilai } & \multicolumn{2}{|c|}{ Skor Hasil Penilaian } & \multirow{2}{*}{$\% \mathbf{P}$} & \multirow{2}{*}{ Kriteria } \\
\hline & & V-1 & V-2 & & \\
\hline \multicolumn{6}{|c|}{$\begin{array}{ll}\text { Kriteria Kegrafikan } \\
\end{array}$} \\
\hline 1. & Penggunaan font (jenis dan ukuran). & 5 & 5 & 100 & Sangat Baik \\
\hline 2. & Desain tampilan. & 5 & 5 & 100 & Sangat Baik \\
\hline 3. & $\begin{array}{l}\text { Tata letak teks, gambar, tabel dan grafik } \\
\text { disajikan secara serasi. }\end{array}$ & 4 & 4 & 80 & Baik \\
\hline 4. & Kualitas cetak & 5 & 5 & 100 & Sangat Baik \\
\hline 5. & Kualitas kertas yang digunakan & 5 & 5 & 100 & Sangat Baik \\
\hline
\end{tabular}

b. Uji coba Terbatas

Tujuan dari uji coba adalah untuk mengetahui kelayakan buku petunjuk praktikum. Uji coba dilakukan secara terbatas yaitu pada 20 mahasiswa kelas KB Angkatan 2013 dengan metode one group pretest-posttest design [8].

Mahasiswa diberi soal pretest yang dikerjakan dalam waktu 45 menit. Setelah itu, mahasiswa diberi penjelasan tentang judul praktikum yang akan dilakukan. Sebanyak 6 judul praktikum dilakukan oleh mahasiswa secara berkelompok. Pengisian MSDS yang ada di buku praktikum dilaksanakan sebelum mahasiswa melakukan kegiatan praktikum di laboratorium. Selama mahasiswa melakukan praktikum, pengamat mengamati aktivitas mahasiswa dalam kelompok. Pada pertemuan terakhir, maka mahasiswa diberikan soal post test yang dikerjakan dalam waktu 45 menit. Selanjutnya, mahasiswa mengisi angket respon.

Hasil dari uji coba terbatas dianalisis secara deskriptif kuantitatif untuk mengetahui kelayakan buku petunjuk praktikum Berikut ini disajikan hasil dari uji coba terbatas:

1) Hasil angket respon mahasiswa

Angket respon mahasiswa diberikan kepada 20 mahasiswa yang telah menggunakan buku petunjuk praktikum yang bertujuan untuk mengetahui pendapat mahasiswa tentang buku petunjuk praktikum.

Berdasarkan data hasil perhitungan angket mahasiswa, didapatkan kesimpulan bahwa buku petunjuk praktikum pada pertanyaan pertama dapat diketahui bahwa 100\% mahasiswa atau sebanyak 20 mahasiswa menyatakan pertanyaan-pertanyaan yang ada dalam buku petunjuk praktikum mudah dipahami, karena menggunakan bahasa Indonesia yang baku dan hal ini didukung oleh jawaban pada pertanyaan keempat dimana semua mahasiswa menyatakan bahwa Bahasa Indonesia yang digunakan dalam buku petunjuk praktikum ini mudah dipahami.

Pada pertanyaan kedua dapat diketahui bahwa 90\% mahasiswa atau sebanyak 18 mahasiswa menyatakan bahwa uraian atau penjelasan yang ada dalam buku petunjuk praktikum tidak sulit untuk dipahami, sehingga mahasiswa dapat menjalankan praktikum dengan lancar. Untuk pertanyaan ketiga, sebanyak 18 mahasiswa menyatakan bahwa buku petunjuk praktikum dapat menumbuhkan rasa ingin tahu terhadap materi yang dibahas. Pada pertanyaan kelima dapat diketahui bahwa sebanyak 19 mahasiswa dapat memahami istilah-istilah yang ada di dalam buku petunjuk praktikum. 
Tabel 5. Hasil Angket Respon Mahasiswa

\begin{tabular}{|c|c|c|c|c|c|}
\hline \multirow{2}{*}{ No. } & \multirow{2}{*}{ Pertanyaan } & \multicolumn{4}{|c|}{ Jawaban } \\
\hline & & Ya & Tidak & $\mathbf{P}(\%)$ & Kriteria \\
\hline 1. & $\begin{array}{l}\text { Apakah pertanyaan-pertanyaan yang ada dalam } \\
\text { buku petunjuk praktikum ini mudah dipahami? }\end{array}$ & 20 & 0 & 100 & $\begin{array}{c}\text { Sangat } \\
\text { Baik }\end{array}$ \\
\hline 3. & $\begin{array}{l}\text { Apakah buku petunjuk praktikum ini dapat } \\
\text { menumbuhkan rasa ingin tahu Anda terhadap } \\
\text { materi yang akan dibahas? }\end{array}$ & 18 & 2 & 90 & $\begin{array}{l}\text { Sangat } \\
\text { Baik }\end{array}$ \\
\hline 4. & $\begin{array}{l}\text { Apakah Bahasa Indonesia yang digunakan } \\
\text { dalam buku petunjuk praktikum ini mudah } \\
\text { dipahami? }\end{array}$ & 20 & 0 & 100 & $\begin{array}{l}\text { Sangat } \\
\text { Baik }\end{array}$ \\
\hline 5. & $\begin{array}{l}\text { Apakah istilah-istilah yang ada dalam buku } \\
\text { petunjuk praktikum ini sulit dipahami? }\end{array}$ & 1 & 19 & 95 & $\begin{array}{l}\text { Sangat } \\
\text { Baik }\end{array}$ \\
\hline 6. & $\begin{array}{l}\text { Apakah penyajian buku petunjuk praktikum ini } \\
\text { membangkitkan motivasi Anda untuk belajar? }\end{array}$ & 17 & 3 & 85 & $\begin{array}{l}\text { Sangat } \\
\text { Baik }\end{array}$ \\
\hline 7. & $\begin{array}{l}\text { Apakah ilustrasi atau gambar yang ada dalam } \\
\text { buku petunjuk praktikum ini dapat membantu } \\
\text { Anda dalam memahami konsep? }\end{array}$ & 20 & 0 & 100 & $\begin{array}{l}\text { Sangat } \\
\text { Baik }\end{array}$ \\
\hline 8. & $\begin{array}{l}\text { Apakah penyajian yang ada dalam buku } \\
\text { petunjuk praktikum menarik atau } \\
\text { menyenangkan? }\end{array}$ & 16 & 4 & 80 & Baik \\
\hline 9. & $\begin{array}{l}\text { Apakah warna teks dalam buku petunjuk } \\
\text { praktikum ini mendukung ilustrasi atau } \\
\text { gambar? }\end{array}$ & 16 & 4 & 80 & Baik \\
\hline 10. & $\begin{array}{l}\text { Apakah jenis huruf dan ukuran tulisan dalam } \\
\text { buku petunjuk praktikum ini membuat Anda } \\
\text { nyaman membaca buku ini? }\end{array}$ & 19 & 1 & 95 & $\begin{array}{l}\text { Sangat } \\
\text { Baik }\end{array}$ \\
\hline 11. & $\begin{array}{l}\text { Apakah uraian atau penjelasan yang ada dalam } \\
\text { buku petunjuk praktikum ini sulit dipahami? }\end{array}$ & 2 & 18 & 90 & $\begin{array}{l}\text { Sangat } \\
\text { Baik }\end{array}$ \\
\hline
\end{tabular}

Pada pertanyaan keenam dapat diketahui bahwa 17 mahasiswa menyatakan penyajian buku petunjuk praktikum dapat membangkitkan motivasi belajar mereka. Hal tersebut sesuai dengan Permendikbud RI Nomor 65 Tahun 2013 [10] yang menyatakan bahwa proses pembelajaran pada satuan pendidikan diselenggarakan secara interaktif, inspiratif, menyenangkan, menantang, memotivasi peserta didik untuk berpartisipasi aktif, serta memberikan ruang yang cukup bagi prakarsa, kreativitas, dan kemandirian sesuai dengan bakat, minat, dan perkembangan fisik serta psikologis peserta didik.

Sebanyak 20 mahasiswa menyatakan bahwa buku petunjuk praktikum sudah dilengkapi dengan gambar yang dapat membantu mereka untuk memahami konsep dan hal ini dinyatakan dalam pertanyaan ketujuh. Untuk pertanyaan kedelapan dan kesembilan, sebanyak 16 mahasiswa menyatakan bahwa penyajian yang ada dalam buku petunjuk praktikum menarik dan warna teks dalam buku petunjuk praktikum mendukung gambar.

Pada pertanyaan terakhir atau kesepuluh pada angket respon mahasiswa didapatkan bahwa 19 mahasiswa merasa nyaman membaca buku petunjuk praktikum, karena kesesuaian antara jenis huruf dan ukuran tulisan yang digunakan. 
2) Hasil Observasi Aktivitas Mahasiswa

Selama siswa melakukan praktikum dengan menggunakan buku petunjuk praktikum, maka dilakukan observasi aktivitas mahasiswa oleh pengamat dengan menggunakan lembar observasi aktivitas mahasiswa.

Tabel 6. Hasil Observasi Aktivitas Mahasiswa

\begin{tabular}{|c|c|c|c|}
\hline No. & Nama & Skor Akhir & Predikat \\
\hline 1 & DH & 85,2 & Baik (B) \\
\hline 2. & AW & 94,4 & Sangat Baik (A) \\
\hline 3. & IS & 92,6 & Sangat Baik (A) \\
\hline 4. & ST & 94,4 & Sangat Baik (A) \\
\hline 5. & ND & 75,9 & Baik (B) \\
\hline 6. & $\mathrm{DN}$ & 92,6 & Sangat Baik (A) \\
\hline 7. & DS & 92,6 & Sangat Baik (A) \\
\hline 8. & NA & 88,9 & Sangat Baik (A) \\
\hline 9. & DP & 87,0 & Sangat Baik (A) \\
\hline 10. & MA & 83,3 & Baik (B) \\
\hline 11. & SA & 90,7 & Sangat Baik (A) \\
\hline 12. & DS & 92,6 & Sangat Baik (A) \\
\hline 13. & $\mathrm{AF}$ & 92,6 & Sangat Baik (A) \\
\hline 14. & NW & 79,6 & Baik (B) \\
\hline 15. & DS & 92,6 & Sangat Baik (A) \\
\hline 16. & $\mathrm{AH}$ & 79,6 & Baik (B) \\
\hline 17. & MP & 85,2 & Sangat Baik (A) \\
\hline 18. & RA & 75,9 & Baik (B) \\
\hline 19. & YW & 92,6 & Sangat Baik (A) \\
\hline 20. & DM & 88,9 & Sangat Baik (A) \\
\hline
\end{tabular}

Semua aktivitas mahasiswa selama melakukan praktikum dengan menggunakan buku petunjuk praktikum berada dalam predikat baik sebanyak 6 mahasiswa dan sebanyak 14 mahasiswa mendapatkan kriteria sangat baik.

Berdasarkan respon mahasiswa dan ditunjang oleh aktivitas mahasiswa, maka dapat disimpulkan bahwa buku petunjuk praktikum memenuhi kriteria kepraktisan.

3) Tes Hasil Belajar

Tes hasil belajar ini disajikan pada pretest dan post test. Pretest diberikan pada mahasiswa sebelum menggunakan buku petunjuk praktikum dan post test diberikan setelah mahasiswa menggunakan buku petunjuk praktikum. Pretest dan post test diberikan kepada 20 mahasiswa jurusan kimia kelas KB angkatan 2013 Universitas Negeri Surabaya. Hasil Pretest dan post test diberikan kepada 20 mahasiswa jurusan kimia kelas KB angkatan 2013 Universitas Negeri Surabaya disajikan pada Tabel 7.

Pada pre test nilai tertinggi adalah 65 dengan predikat cukup $(\mathrm{C})$ dan nilai terendah adalah 40 dengan predikat kurang (D), sehingga belum ada mahasiswa yang tuntas pada saat pre test. Untuk post test didapatkan nilai tertinggi adalah 100 dengan predikat sangat baik (A) dan nilai terendah 75 dengan predikat baik (B), sehingga semua mahasiswa tuntas.

Berdasarkan hasil belajar mahasiswa dapat disimpulkan bahwa buku petunjuk praktikum memenuhi kriteria efektif. 
Tabel 7. Hasil Tes Belajar

\begin{tabular}{|c|c|c|c|c|c|}
\hline \multirow{2}{*}{ No. } & \multirow{2}{*}{ Nama } & \multicolumn{2}{|c|}{ Nilai Pre Test } & \multicolumn{2}{|c|}{ Nilai Post Test } \\
\hline & & Nilai & Predikat & Nilai & Predikat \\
\hline 1. & DH & 50 & Kurang (D) & 95 & Sangat Baik (A) \\
\hline 2. & AW & 65 & Cukup (C) & 100 & Sangat Baik (A) \\
\hline 3. & IS & 35 & Kurang (D) & 75 & Baik (B) \\
\hline 4. & ST & 40 & Kurang (D) & 75 & Baik (B) \\
\hline 5. & ND & 30 & Kurang (D) & 85 & Baik (B) \\
\hline 6. & DN & 60 & Cukup (C) & 95 & Sangat Baik (A) \\
\hline 7. & DS & 60 & Cukup (C) & 80 & Baik (B) \\
\hline 8. & NA & 55 & Kurang (D) & 90 & Sangat Baik (A) \\
\hline 9. & DP & 55 & Kurang (D) & 80 & Baik (B) \\
\hline 10. & MA & 60 & Cukup (C) & 90 & Sangat Baik (A) \\
\hline 11. & SA & 55 & Kurang (D) & 80 & Baik (B) \\
\hline 12. & DS & 60 & Cukup (C) & 90 & Sangat Baik (A) \\
\hline 13. & $\mathrm{AF}$ & 50 & Kurang (D) & 100 & Sangat Baik (A) \\
\hline 14. & NW & 50 & Kurang (D) & 80 & Baik (B) \\
\hline 15. & DS & 55 & Kurang (D) & 100 & Sangat Baik (A) \\
\hline 16. & $\mathrm{AH}$ & 40 & Kurang (D) & 85 & Baik (B) \\
\hline 17. & MP & 55 & Kurang (D) & 100 & Sangat Baik (A) \\
\hline 18. & RA & 55 & Kurang (D) & 95 & Sangat Baik (A) \\
\hline 19. & YW & 40 & Kurang (D) & 90 & Sangat Baik (A) \\
\hline 20. & DM & 50 & Kurang (D) & 90 & Sangat Baik (A) \\
\hline
\end{tabular}

\section{KESIMPULAN}

Berdasarkan analisis data dan pembahasan, dapat disimpulkan bahwa:

1. Kevalidan buku petunjuk praktikum kimia anorganik yang disertai dengan Material Safety Data Sheet ditunjukkan dengan validitas berdasarkan kriteria isi dengan persentase sebesar 95\%, validitas berdasarkan kriteria kebahasaan memperoleh persentase sebesar $86 \%$, validitas berdasarkan kriteria penyajian mendapatkan persentase sebesar $94 \%$, validitas berdasarkan kriteria kegrafikan dengan presentase sebesar $96 \%$.

2. Kepraktisan buku petunjuk praktikum kimia anorganik yang disertai dengan Material Safety Data Sheet ditunjukkan dengan angket respon mahasiswa yang rata-rata memberikan respon positif dan hasil observasi aktivitas mahasiswa yang rata-rata mendapatkan kriteria sangat baik.

3. Keefektifan buku petunjuk praktikum kimia anorganik yang disertai dengan Material Safety Data Sheet ditunjukkan oleh hasil belajar mahasiswa yang memperoleh ketuntasan $100 \%$ pada saat post test.

\section{DAFTAR RUJUKAN}

Menteri Perindustrian Indonesia. 2013. Peraturan Menteri Perindustrian Indonesia Nomor 23/MIND/PER/4/2013 tentang Perubahan atas Peraturan Menteri Perindustrian Nomor 87/MIND/Per/9/2009 tentang Sistem Harmonisasi Global Klasifikasi dan Label Baban Kimia. Jakarta: Kementerian Perindustrian.

Moran, Lisa dan Tina Masciangoli. 2010. Keselamatan dan Keamanan Laboratorium Kimia: Panduan Pengelolaan Kimia dengan Bijak. Washington DC: The National Academies Press. 
National Safety Council. 2011. Annual Report: Highlighting The Successes Of The Past Year In Preventing Injuries And Saving Lives. Washington DC: NSC.

Peraturan Menteri Pendidikan dan Kebudayaan Republik Indonesia. 2013. Permendikbud RI Nomor 65 Tabun 2013 tentang Standar Proses Pendidikan Dasar dan Menengah. Jakarta: Mendikbud.

Plomp, Tjeerd. "Educational Design Research: An Introduction” Dalam Tjeerd Plomp dan Nienke Nieeven (Ed.). 2010. An Introduction to Educational Design Research. Enschede: SLO. Netherland Institute for Curriculum Development.

Utomo, M. Pranyoto, Sari, Rr. Lis P., Budiasih, Kun S. 2010. Penerapan praktikum berorientasi aplikasi pada mata kuliah praktikum kimia anorganik I dan II. Prosiding Seminar Nasional Kimia dan Pendidikan Kimia. Yogyakarta: Jurusan Pendidikan Kimia UNY

Zainuddin, M. 2001. Praktikum. Jakarta: Universitas Terbuka.

Riduwan. 2011. Skala Pengukuran V ariabel-V ariabel Penelitian. Bandung: Alfabeta.

Sadiman, Arief S., Rahardjo, R., Haryono, Anung., Rahardjito. 2011. Media Pendidikan : Pengertian, Pengembangan dan Pemanfaatan. Jakarta: PT. Raja Grafindo Persada.

Sugiyono. 2012. Metode Penelitian Pendidikan: Pendekatan Kuantitatif, Kualitatif, dan R\&D. Bandung: Alfabeta. 